\title{
Meaning-Making in Science from the Perspective of Students' Hybrid Language Use
}

\author{
Pia Nygård Larsson ${ }^{1}$ (D) Anders Jakobsson ${ }^{1}$
}

Received: 26 October 2018 / Accepted: 28 May 201 / Published online: 24 June 2019

(C) The Author(s) 2019

\begin{abstract}
In this article, we assume that discursive language aspects of science education are highly intertwined with students' knowledge-building and meaning-making in science. In an empirical case study, we investigate secondary students' (ages 15 to 16) discursive language use during group interactions. The focus is on how students define and explain the content within everyday or scientific discourses and how their negotiations may influence discussion outcomes. The results suggest that students who can move between everyday and scientific languages benefit from this exchange, while students who only use colloquial language or relate the content to everyday experiences become disadvantaged. Furthermore, important general success factors are students' abilities to establish solid relationships between words, expressions, and scientific terms to discuss, explain, and evaluate the scientific content. The results show important differences in discursive use of language within various school environments.
\end{abstract}

Keywords Language game · Scientific discourses · Small-group interactions · Students' language use $\cdot$ Systemic functional linguistics

\section{Introduction}

A growing number of researchers have recently focused on school science instruction from a language or a discursive perspective (e.g. Knain, 2015; Serder \& Jakobsson, 2016; Wallace, 2004). In these contexts, science education constitutes a specific language activity or encounter between different discourses or linguistic worlds (Kambrelis \& Wehunt, 2012). This description implies that school science instruction may be a hybrid of languages (Bakhtin, 1981) or a specific discourse, in which scientific expressions are mixed with colloquial or everyday language usages. Furthermore, science instruction and

Pia Nygård Larsson

pia.nygard-larsson@mau.se

1 Faculty of Education and Society, Malmö University, 20506 Malmö, Sweden 
international student assessments (such as Programme for International Student Assessment (PISA)) frequently relate scientific issues to everyday contexts, implying that students must distinguish and move between discourses and interpret the tasks as specific scientific problems to provide satisfactory answers (Nygård Larsson \& Jakobsson, 2017; Serder \& Jakobsson, 2016). This type of language use in science education, with its distinctive linguistic and structural features, has also been described within the framework of systemic functional linguistics (SFL) (Fang, 2005; Fang \& Wei, 2010; Halliday \& Matthiessen, 2004). Several studies have shown that language demands placed on students often go beyond just conceptual challenges (e.g. Seah, Clarke, \& Hart, 2011). In other words, learning science means developing both conceptual and discursive understanding, which includes the semantic relationships or specific thematic patterns (Lemke, 1990) and the distinctive linguistic and structural characteristics of scientific discourse.

An important conclusion in these studies is that teachers and students have to develop awareness of different language usage within science and science instruction in order to facilitate and enhance the meaning-making process. Other studies indicate that this conclusion may be particularly significant for many multilingual students or those in urban school environments (e.g. Brown \& Spang, 2008). Another conclusion implies that these discursive and linguistic demands on students are set early in compulsory school, both in receptive and productive respects (González-Howard, McNeill, Marco-Bujosa, \& Proctor, 2017; Seah, 2016; Seah \& Yore, 2017). In all these studies, students encounter different reading and writing tasks, combined with oral interaction, as a way of enhancing their meaning-making processes (e.g. Gibbons, 2003; Rivard, 2004).

However, we argue that various discursive language aspects are highly intertwined with students' development of conceptual knowledge in science. Therefore, this study is aimed at exploring secondary students' (ages 15 to 16) small-group interactions in science classrooms. The study focuses on students' negotiations about educational content and investigates how their discursive language usage may influence the outcome of these discussions.

\section{Theoretical Perspectives}

\section{Science Education and Instruction as a Hybrid of Languages}

Science education is a disciplinary discourse with specific literacy demands or ways of reading, writing, speaking, doing, and thinking (Halliday \& Martin, 1993). Gee (1996) describes these disciplinary discourses as secondary discourse, as opposed to colloquial discourses, and defines literacy as the ability to master these secondary discourses. Therefore, these discourses involve the ability to participate and communicate in functional ways within various social practices. This also implies a close, complex connection between language use and knowledge-building. In this sense, discursive language use within science education comprises aspects of both fundamental and derived scientific literacy (Chin, Yang, \& Tuan, 2016; Hand, Norton-Meier, Gunel, \& Akkus, 2016; Norris \& Phillips, 2003).

However, Yore and Treagust (2006) describe science education as a three-language problem, as students move between home, school, and scientific discourses. In their 
movement between these discourses, students are expected to understand that words and expressions have different meanings or connotations in different contexts. Words and their meanings are not totally separable or mutually exclusive, but are related and interwoven, and operate at different levels of students' lives (Gee, 1999). Furthermore, the use of different discourses implies a need to understand that scientific languages used in school have significant definitions, meanings, and usage, which diverge to a great extent from an everyday way of using language. In this light, the language usage in science and science education becomes specific choices of words, grammar, idioms, and metaphors (Lemke, 1990) and ways of excluding or including common elements of everyday life. Several studies within science education (e.g. Brown \& Spang, 2008; Serder \& Jakobsson, 2016) indicate that students are often unaware of these types of distinctions, which may lead to limitations in the process of learning and understanding science.

Furthermore, science discourse is not exclusively used in most science classrooms, and the significance and meaning of words, terms, and expressions are often discussed or explained in an everyday perspective and language. Several scholars have stressed this hybrid (Bakhtin, 1981) or interlanguage nature of learning spaces in science instruction (Lemke, 1990) and student-to-student interaction (Olander, 2010). According to Lemke (1990), science language may be gradually developed, using a scaffolding method. The students will first begin to grasp some semantic relationships, with the help of colloquial language, and then gradually move toward scientific language and terms when the words are appropriated. During this process, both students and teachers normally use a type of hybrid language to facilitate development into more scientific language use.

In these contexts, one problem is that language usage in education usually takes place on an implicit level, which may lead to confusion among students (Kambrelis \& Wehunt, 2012). In such learning environments, teachers often adopt a hybrid language without clarifying the contexts in which words and expressions belong. In a study by Brown and Spang (2008), teachers were asked to use an explicit instructional strategy of double talk that comprised both vernacular and scientific languages when explaining scientific ideas for the students. The aim was to help the students develop a relationship between everyday and scientific expressions and experiences. The results indicate that students exposed to the new strategy were able to explain scientific phenomena by relating to their colloquial language to a greater extent than the control group. Other studies (e.g. Serder \& Jakobsson, 2016) assert that using an unconsidered hybridity in science classrooms may implicate increased complexity, obvious risks for misunderstandings, and insufficient learning outcomes. However, the authors also note that conscious language use may create opportunities to improve conditions for learning. Furthermore, Tan, Calabrese Barton, Turner, and Gutiérrez (2012) argue that important ways of empowering science instruction include making hybrid spaces explicit for students by comparing and merging their everyday worlds and colloquial language with the language of science.

An obvious conclusion from these studies is that science instruction should strive to explicitly facilitate students' discursive language use, in parallel with working with science content to enhance learning outcomes. In terms of the science teacher's role, Hanrahan (2006) suggests that successful teachers intentionally use hybrid discourses to include all students in classroom discussions. Wallace (2004) stresses that a deliberate development of hybrid meanings is the result of teacher-student negotiations in 
the third space (Bhabha, 1994). This space is defined as an abstraction of space and time location, which invites students to create a joint construction of interpretations between everyday experience and language use, in relation to the language of science.

\section{Linguistic Worlds in Science Education and Instruction}

One way to understand the differences in language usage within discourses is by using the metaphor of discursive mobility (Nygård Larsson, 2011). This concept describes the transformation of knowledge and language as a movement between and within different discourses. Discursive mobility involves movements between everyday and scientific discourses, as well as concrete, abstract, specific, and general meanings within these discourses. A high level of discursive mobility may imply that teachers consciously move between different expressions to maximize students' learning opportunities (Nygård Larsson, 2018). Similarly, students need to develop an awareness of discursive mobility according to specific language and literacy demands in science instruction. In a study of student-to-student interaction, Nygård Larsson and Jakobsson (2017) found that successful students have, to a greater extent than others, developed an ability to move back and forth between different levels of language use when talking about science.

However, the grammatical features, the significance of words and terms, and the typical semantic patterns (Lemke, 1990) that constitute scientific languages may create difficulties for students who are untrained in the language usage of science (Brown \& Spang, 2008). Apart from specific scientific terms (such as photosynthesis, chemical reaction, and electron), there are several everyday words that may also have a specific definition and use in science (such as heat, work, force, and energy). Studies (Fang, 2006; Seah et al., 2011; Seah, Clarke, \& Hart, 2014) show that different usages of these kinds of words often create confusion for students. In addition, several subject-typical words (such as reference, constant, pattern, and factor) may have different meanings in different disciplines, which further increases complexity (Serder \& Jakobsson, 2016). In addition to these words, more general academic words (such as explanation, development, consist of, and consider) are used in a school context, which may also have slightly different meanings in other school subjects (Lindberg \& Johansson Kokkinakis, 2007). There may be an obvious risk in overlooking students' difficulties with such words if the science teacher has a one-sided focus on how they are used in science.

However, Halliday and Martin (1993) stress that difficulty understanding the language of science does not only exist at a word level. A technical language (technicality) goes beyond the use of individual words and defined technical terms. The scientific terms derive their meaning and value from being taxonomically organized, which implies that semantic relationships become central for understanding science concepts (Lemke, 1990). However, technical terms and abstract entities are crucial parts of academic knowledge production, and an essential way of constructing scientific terms and words is through using grammatical metaphors (Halliday \& Martin, 1993), such as nominalizations. Many nominal groups also contain complex scientific processes (such as cell division and evolution), which further contribute to information density. 


\section{Language Usage in Science Education in Different Classroom Perspectives}

Several studies have shown that a discursive language-focused instructional strategy is particularly important for many multilingual students or those in low-performing school environments (González-Howard et al., 2017; Seah \& Yore, 2017). For example, the results from Brown and Spang's (2008) study point to the need to teach science from a specific discursive language perspective. The findings show significant progress in these student groups when it comes to their ability to create accurate, valid relationships between everyday experiences and language use and the language of science, which essentially increases the probability of a deeper understanding of the subject content. However, the results also indicate that this type of explicit language focus in science education is beneficial for all students. Another study in similar school environments shows that most students display some misunderstandings of concepts in physics, due to discursive and linguistic challenges (Clerk \& Rutherford, 2000). These results are in line with Seah et al.'s (2011) study, which investigated language appropriation about expansion by analyzing students' usage of lexico-grammatical resources (Halliday \& Matthiessen, 2004). The analysis identifies language features on which students need to focus on to express an understanding of density that aligns with scientific perspectives. This implies the importance of the ability to logically link words together by using appropriate language resources such as conjunctions (such as so, because, and therefore) in a productive way when explaining scientific phenomena. Moreover, the findings highlight teaching strategies for overcoming the discursive and linguistic challenges when explaining density, which complement existing studies that unilaterally focus on conceptual change.

Rivard's (2004) results suggested that low-performing students succeed to a greater extent in problem-solving situations and developed a deeper understanding of ecology concepts when they were engaged in explorative peer discussions of explanatory tasks. However, the results also highlight that these students particularly benefit if these activities constitute a mixture of oral and written tasks. In the context of systemic functional linguistics, explicit attention to students' oral and written language usage supports their content and language development (Fang, 2005, 2006; Gibbons, 2003; Halliday \& Martin, 1993; Schleppegrell, 2013). Furthermore, language usage is considered functional, so it varies depending on the specific context and activity. In a scientific context, the process of explaining involves the ability to identify, elaborate, and clarify how or why different scientific phenomena occur and how they are connected. On the other hand, describing involves activities such as classification, decomposition, and comparison. Therefore, an important implication is that science instruction has to strengthen students' abilities to use language according to various situations and purposes.

From a slightly different perspective, several studies concerning multilingual students have shown the advantages of explicit usage of students' first languages in science. In a South African study by Msimanga and Lelliott (2014), students were encouraged to use their first languages, simultaneously with English, during smallgroup discussions to establish relationships between different experiences and languages. The results indicate that the approach works as a legitimate resource for science learning, especially when students' tasks included difficult or complex concepts. In a Swedish context, Karlsson, Nygård Larsson and Jakobsson (2018, 2019) studied 
language usage during science lessons, in which students were encouraged to use their first language (Arabic) in parallel with their second language (a translanguaging practice) when discussing and negotiating scientific issues in student-to-student interactions. The analysis shows that shifting between first and second languages was an important prerequisite for developing new knowledge and contributed to the students' ability to move between everyday and scientific discourses.

\section{Study and Research Questions}

In this study, we aim to explore students' small-group interactions in secondary science classrooms. The study and analyses focus on students' discussions of PISA items and their language use within everyday and scientific discourses and investigate how this discursive language use may influence the outcome of these discussions. The main purpose of the study is to explore students' authentic use of language by studying their negotiations about terms, words, and expressions when they were involved in problemsolving in school science. The research questions are:

- What characterizes students' discursive use of language when negotiating scientific content?

- How, and to what extent, do students successfully define and explain subject-related content within scientific and everyday discourses?

\section{Methodological Description and Consideration}

The data analyzed in this article constitute a sub-study within the framework of a larger project that focuses on language and discursive perspectives (e.g. Brown \& Spang, 2008; Kelly, 2012; Serder \& Jakobsson, 2016) on school science in Sweden (SONAT project). The total data set of the project comprises extensive, video-recorded, ninthgrade (ages 15 to 16) science-instruction material at six Swedish schools. These recordings are mainly documentation of the regular curriculum for 3 weeks in these schools. A total of 205 students and 14 teachers were involved in the study. The data was gathered in schools showing a result-rate distribution, with respect to grade mean value by school average, either in the lowest 25 th percentile (p25) or in the highest 75 th percentile (p75) in all of Sweden. Based on this, the data was collected in schools that were considered to be typical low-performing or high-performing school environments.

However, a smaller part of the total data set comprised video recordings of situations in which students worked with a PISA task (Mary Montagu, Appendix 1). These recordings form the basis for the analysis in this article. The students had no specific preparation for the task when the data was collected. However, related scientific content is normally included in the regular curriculum in lower secondary schools in Sweden. The students, who were divided in small groups, were asked to determine the correctness of some statements and discuss their selection of different answer options. The classroom context was that the task should be processed in groups of three to four students, and each group should independently come up with a common answer. The 
main purpose of this design was to create an educational context in which students' language use became visible when discussing scientific issues in small-group interactions. The present study focused on the following statements in the tasks:

- Vaccination is an attempt to use the body's own immune system against diseases

- Antibiotic treatment is an attempt to use the body's own immune system against diseases

- Antibiotic treatment is effective against viral diseases such as smallpox

(PISA; Mary Montagu Question 1. Translation of the Swedish version used in the classrooms. Therefore, the third statement differs to some extent from the English version in Appendix 1.)

This article analyzed data from one classroom at four different schools. Two lowperforming (L) and two high-performing $(\mathrm{H})$ schools were included, which was also reflected in students' socio-economic background. All of the students in the two schools with the highest grade mean value were Swedish, and $75 \%$ of parents had a post-secondary education. In the two schools with the lowest grade mean value, $30 \%$ of the parents had post-secondary education, and students' backgrounds were more varied, with a high percentage of migrant backgrounds.

The part of the total data set in which the students worked with PISA items comprised video recordings of $163 \mathrm{~min}$ of interactions in 21 groups (11 from lowperforming schools and 10 from high-performing schools).

In the first phase of the analysis, the data was reduced by removing parts in which the students did not engage in any conversations related to the content or there was partial recording failure. Ten group conversations, representing a total of $86 \mathrm{~min}$ of recordings, were considered relevant and transcribed. Five of these group conversations came from low-performing schools (55\% of $86 \mathrm{~min}$ ), and five came from highperforming schools (45\% of 86 min). The 10 groups were named L1-L5 and H1-H5.

Finally, Mary Montagu Question 1 was the focus of this article, so we omitted other parts of the transcribed conversations for the qualitative analysis, as well as situations where the students mainly spent time reading, thinking, or writing. This resulted in approximately $50 \mathrm{~min}$ of active discussions and student language use for detailed analysis.

The recordings were transcribed verbatim. However, adaptations were made to written language conventions to some extent. Exact pronunciation and precise measurements of the pauses were excluded, and punctuation marks were used. Omitted parts of the transcript were marked with /.../.

The project addressed ethical considerations and permissions required to videotape students in class and took into account the prevailing principles of research ethics (Swedish Research Council, 2011) in collecting and processing the material.

The two researchers analyzed the transcripts independently. Thereafter, the results from the analyses were compared before mutual agreement between the researchers could be established. Thus, both researchers have identified the main results, in relation to the research questions. The results of the analysis are categorized and presented in the "Results" section, in Tables 1 and 2, and further exemplified by Excerpts 1-4. The focus in the analytic process was (a) students' use of words, expressions, and terms that 
may be clarified in this type of interaction (e.g. Jakobsson, Mäkitalo \& Säljö, 2009) and (b) the group members' common ability to find solutions and their discursive language use during this process (Nygård Larsson \& Jakobsson, 2017). This analysis was partially based on Wittgenstein's later framework $(1953 / 1997,1969)$ and other researchers' interpretation of this framework (e.g. Wickman, 2004).

\section{Metaphor of Language Games-an Analytic Perspective}

In terms of analyzing students' interactions from a discursive perspective, several researchers in science education (Serder \& Jakobsson, 2016; Wickman \& Östman, 2002; Wickman, 2004) have been inspired by Wittgenstein's later work (1953/1997, 1969). One concept in this framework consists of the language game metaphor. From an analytic perspective, this concept implies the actual situations in which students interact because they have something to say to one another, rather than limiting their attention to the objects about which they are speaking. According to Wittgenstein (1953/1997), language is interwoven with ways of acting. Connections between words, utterances, and expressions are not simply found in theory, but in the activity itself. Therefore, students' actions and utterances acquire their meaning as parts of a language game, in which words and terms have distinct connotations, definitions, or a specific family of meanings (Wittgenstein, 1953/1997, paragraph 65-67). In these situations, meaning becomes a process that is defined as the situated use of words in language (1953/1997, paragraph 43). This also implies that students' talk must be related to the situational and discursive use of words, terms, and expressions (Lemke, 1990; Nygård Larsson \& Jakobsson, 2017; Serder \& Jakobsson, 2016).

However, in this study, we interpreted Wittgenstein's framework on the basis that interactions contain naturally occurring situations of negotiation about the use of scientific words and their meaning and definition. This type of situation was particularly valuable in the analysis, as negotiations increase the likelihood of making visible students' use of words and expressions. Nevertheless, some things in the language game are standing fast (Wittgenstein, 1969). According to Wittgenstein, things that are standing fast are "the immediately intelligible" (p. 148), which implies that the meaning of a word seems to be obvious for participants in the specific situation, so no further negotiations are needed to create a common ground. However, other things do not stand fast in the language game, which may create gaps (Wickman, 2004) or misunderstandings in the meaning-making process. In this study, an example would be situations in which the groups discuss the PISA task without using a common starting point or negotiating relevant constituent words or terms. This kind of gap in the interaction is particularly exemplified by Excerpt 3 in the "Results" section.

\section{Results}

This section starts by summarizing the main results of the analysis in overall tables (Tables 1 and 2) and then describes the actual analysis, with the help of four excerpts of student discussions. In the tables, group interactions are categorized with respect to the 
Table 1 Overview of students' language use when discussing the statement: Vaccination is an attempt to use the body's own immune system against diseases

Short reply, or using colloquial or vague Elaborate or specific explanation referring to expressions when explaining the process antibodies and white blood cells

- So, you inject the disease and then it will help the immune system (group H3).

Similar: H5, L1, L4, L5.

See also group L2, Excerpt 4.

- You must use the immune system. So, if you can handle it once... so it's... like...you always handle it. If you get it back, kind of, if you get... what the hell is it called...vomiting. Then your immune system will cope at last. Then if you get it again you will handle it again. Like, your immune system will not lose. Do you get it? (group L3).

- Yes, then you trigger...like this...so it comes out... antibodies (group H4).

Similar: H2 (white blood cells).

- ... the body ... builds up antibodies which can then protect against the disease. They are prepared ...

- They are saved so that they are in the body. Next time you get the disease ... there are already antibodies ready /.../

- You're injecting the disease just a little bit so you ... like this ... it will not be dangerous. It's so little. The body fixes so you have white blood cells toward it.

(group H1). See Excerpt 1.

degree of discursive language usage in terms of elaborated explanations and scientific terms including definitions and relations.

The first statement (Vaccination is an attempt to use the body's own immune system against diseases) in the PISA task Mary Montagu Question 1, was not very challenging for most of the groups. However, there were significant differences in how students approached, discussed, and explained the

Table 2 Students' language use when discussing the statements: Antibiotic treatment is an attempt to use the body's own immune system against diseases, and Antibiotic treatment is effective against viral diseases such as smallpox

Discusses antibiotics but does Mentions bacteria, without specific not mention bacteria. Relates to relation to other terms. Relates to everyday experiences everyday experiences
Defines terms and discusses the relation between bacteria, virus, and antibiotics
- Does everyone know what antibiotics are? It's a medicine (L5). Similar: L3

- I remember...I had...just...I think it was a virus...or it was.../.../

- But I think you use antibiotics for viruses

- You think?

- What's it called... strepto... something... that I had in my foot. I think it was a virus (H3).

See also: L2, Excerpt 4.
- They make the bacteria...

- You know, when you have... this strange thing in your throat. When it - Antibiotics are just against really hurts, really red. Then you usually take antibiotics, because then you have many viruses and all that. So, it must help (L4)

Similar response: $\mathbf{H 5}$.

See also: L1, Excerpt 3.
- Antibiotics are just a poison against bacteria /.../ bacteria. Not virus (H1)

- And bacteria can be cured with antibiotics

- Yes

- Virus cannot (H4)

- Antibiotics sit on the cell wall then... (H2). See Excerpt 2. 
vaccination process. Three group conversations were categorized as more elaborate or specific by referring to scientific terms such as antibodies and white blood cells, which were not mentioned in the task (Question 1). The other discussions about this issue were too general or vague, or mainly consisted of colloquial expressions. Table 1 describes similarities and differences in students' language use in the ten group conversations relating to the first statement in Question 1.

The analysis also showed that many students perceived the statements Antibiotic treatment is an attempt to use the body's own immune system against diseases and Antibiotic treatment is effective against viral diseases such as smallpox as challenging. This was related to the groups' ability to identify and define relevant terms (such as bacteria, virus, and antibiotics) and their ability to semantically relate them (Lemke, 1990) within a scientific knowledge structure and discourse. These definition processes led to confusion concerning specific words for some groups (column 2, Table 2). Table 2 describes similarities and differences in students' language use in the group conversations related to these statements in Question 1.

In summary, the utterances or conversations in the right column in the tables are more aligned with the scientific content within this discourse, while those in the left or middle column are more general or colloquial and related to everyday experiences to a greater degree. On the other hand, the relationship between everyday experiences and the science content seem to be important in the majority of the group discussions. We will return to this relationship in the next section of the result description. In this section, we selected four conversation sequences that together represent the results from each column in the tables and thus illustrate the various discursive language usages within the ten groups (Excerpts 1-4). These examples consist of two excerpts each from low-performing and high-performing schools.

\section{Defining and Explaining Within a Scientific Discourse}

In the first example, students discuss the credibility of the following statement (1): Vaccination is an attempt to use the body's own immune system against diseases.

Excerpt 1 from school H1: Martin, Andre, and Sandra

1. Martin: You get some of the disease

2. Andre: Yeah. Like this ... the body ... builds up antibodies which can then protect against the disease. They are prepared ...

3. Martin: They are saved so that they are in the body. Next time you get the disease ... there are already antibodies ready

4. Andre: Then there is, like, a defence against ... /.../

5. Sandra: If you are vaccinated you may get the disease, which (...inaudible)

6. Andre: Yeah, you'll get it but it, like, never breaks out

7. Martin: You're injecting the disease just a little bit so you ... like this ... it won't be dangerous. It's so little. The body fixes so you have white blood cells toward it 
In the discussion, Martin initially states, "You get some of the disease" (1). Andre supports this claim and develops it further by adding that "the body ... builds up antibodies, which then can protect against the disease. They are prepared" (2). Through these statements, Andre also introduces the scientific word antibodies, which is not mentioned in this task (Question 1). Furthermore, his utterance indicates that he wants to establish the relationship that the purpose of the vaccination is to stimulate the body to build up antibodies that can protect against future disease. This interpretation is further clarified when Martin suggests that "They are saved so that they are in the body. Next time you get the disease ... there are already antibodies ready" (3), and also by Andre when he states, "Then there is, like, a defence against..." (4).

By using Wittgenstein's concept of standing fast in the analysis, it is possible to assert that the main purpose of the conversation up to this point is to establish the relationship between the meanings of vaccination-build up antibodies-protect against the disease in the future, which stands fast in the discussion from this point onward. In all cases, this applies to the two students who were active in the discussion. When Sandra later says, "If you are vaccinated you may get the disease, which ..." (5), she is possibly seeking clarification of Martin's first statement ("You get some of the disease"). Andre responds to Sandra by saying, "you'll get it but it, like, never breaks out" (6). Martin elaborates further by saying, "You're injecting the disease just a little bit so you ... like this ... it won't be dangerous. It's so little. The body fixes so you have white blood cells toward it" (7). By saying this, he introduces another scientific term that is not mentioned in the task: white blood cells.

The discussion starts and ends with the everyday expressions: "You get some of the disease" (1), "You're injecting the disease just a little bit" (7), and "The body fixes" (7). However, the discussion moves toward a more scientific discourse with the help of words and scientific terms that are used in a productive way. Clear examples of this are antibodies and white blood cells, which help focus the discussion and create a mutual language within a scientific discourse. Therefore, it is evident that the students use a hybrid language (Bakhtin, 1981), including features of both everyday and scientific discourses in a kind of interlanguage (Lemke, 1990; Olander, 2010). In this way, the students show productive discursive mobility (Nygård Larsson, 2011; Nygård Larsson \& Jakobsson, 2017) and manage not only to give the correct answer to the statement but also to clarify and explain the process of vaccination and immunization, largely within a scientific discourse. It is particularly important to observe the students' use of several general and everyday expressions, such as build up, protect against, is prepared, is saved, is a defence against, and break out. These expressions clarify and specify the various processes involved. By using these expressions, in combination with scientific terms and words, the students define the terms and their relationships in order to explain the processes and elaborate and clarify the explanation of a scientific phenomenon (Halliday \& Martin, 1993). This in turn, may be compared with group L3 (see Table 1), which uses everyday expressions and describes the processes more vaguely by using verbs such as can handle, get back, will cope, and will not lose.

In the second example, students in another group discuss the two following statements: (2) Antibiotic treatment is an attempt to use the body's own immune system against diseases and (3) Antibiotic treatment is effective against viral diseases such as smallpox. 
Excerpt 2 from school H2: John, Cecilia, Patrik, and Katarina

8. John: Then ... shall we see ... antibiotics sit on the cell wall then ... so ...

9. Cecilia: They break down all cells regardless of whether they are good or bad (making quotation marks in the air with her fingers when she says, 'good or bad')

10. Patrik: Yeah

11. John: No, they only break down the virus cells

12. Cecilia: No

13. John: Or bacteria

14. Cecilia: You can't break down viruses

15. John: Bacteria, I mean...

16. Cecilia: No, they break down the natural ones also ... only that you get side effects

17. John: ...they sit on the cell wall (simultaneously)

/.../

18. Cecilia: So, it could alleviate it ... but it will not be ... it will not disappear

19. Katarina: It may not be effective (...inaudible)

20. John: But a virus does not have a cell wall

The discussion starts when John focuses directly on how the antibiotic works in the body at a cellular level by claiming "antibiotics sit on the cell wall" (8). By moving to this microlevel, he immediately takes the discussion into a scientific discourse. Cecilia seems to hold the discussion at the same level when she asserts "They break down all cells regardless if they are good or bad" (9). Notably, she makes quotations marks in the air when she says "good or bad," which suggests that she wants to show that she is aware of the vagueness of this description. By this utterance, she also suggests that antibiotics attack both the invading bacteria as well as the body's own cells. John then responds by claiming "No, they only break down the virus cells" (11). This proposal meets immediate opposition from Cecilia, who asserts that "You can't break down viruses" (14). She is probably referring to the fact that the antibiotic treatment does not affect virus cells. At this point, John has realized his mistake and quickly tries to correct the previous statement by asserting "Or bacteria" (13) and "Bacteria, I mean..." (15). He then immediately adds "... they sit on the cell wall" (17). We interpreted the sequence to mean that John's previous statement (11) was a slip of the tongue and that he is aware that antibiotics are a treatment against bacterial infections.

At the same time, Cecilia's focus remains on the issue of what an antibiotic treatment causes at the cellular level when she says "No, they break down the natural ones also ... only that you get side effects" (16) and that "it could alleviate it ... but it will not be ... it will not disappear" (18). These statements indicate that Cecilia is aware that an antibiotic treatment is a relatively vigorous treatment that can result in side effects. John, on the other hand, continues the parallel issue of whether antibiotics combat bacteria or viruses by claiming, "But a virus does not have a cell wall" (20). This statement implies that he is aware that antibiotic treatment cannot be directed against viruses because they lack cell walls to which the antibiotic can attach.

Using Wittgenstein's framework, it is feasible to argue that the relation is established between antibiotic treatment-combating bacteria-and not virus and this relationship finally stands fast in the conversation. We argue that this relationship constitutes an important presumption for the group when the students determine the accuracy of the statements. 
In this excerpt, the students discuss the validity of the statements within a scientific discourse, with the help of scientific terms and words. Above all, the conversation focuses on what happens with the antibiotics at a micro-, or cellular level, which is typical for a scientific approach. In this perspective, the excerpt is an example of a relatively initiated reasoning about the issue, in which the students seek to explain the phenomenon within a scientific discourse.

We argue that the above excerpts illustrate how group members establish relationships between words, expressions, and scientific terms, creating the conditions necessary to discuss and successfully evaluate the statements. In the first example, most of the group members establish a mutual agreement about the relationship between vaccination-build up antibodies-protect against the disease in the future. We also argue that this assumption constitutes a prerequisite to solving the problem. Even in the second example, the students establish a mutually agreed relationship. In this case, the relationship between antibiotic treatment-combating bacteria-and not virus is established and finally stands fast. We argue that this kind of discussion about scientific issues constitutes an important common ground for solving the task. Equally important, the students seek to identify the issue as a scientific one and strive to clarify and explain the processes involved (Halliday \& Martin, 1993) within a scientific knowledge structure and discourse.

\section{Using Everyday Experiences in Negotiating About the Task}

In the third example, a group of students are involved in a conversation using the same statements (2 and 3 ) as the students in the previous discussion.

Excerpt 3 from school L1: Felicia, Peter, and Tony

21. Felicia: I think antibiotics are killing ...

22. Peter: Bacteria

23. Felicia: Well, kill diseases

24. Tony: Yeah, then it's wrong isn't it (referring to statement 2)

/.../

25. Tony: I have had some sort of viral infection. I got no antibiotics (referring to statement 3)

26. Felicia: What do you get antibiotics against ... it's against viruses, isn't it?

27. Tony: It's against tonsillitis and such

28. Felicia: Yeah, it's a virus, isn't it?

29. Tony: Uhh, no clue

30. Peter: Yeeeah ... it ...

31. Tony: I don't know. I got it. Well you get. Maybe ...

32. Felicia: What do antibiotics contain?

33. Peter: ... effective against viral... (reading aloud)

34. Tony: It's a kind of poison, isn't it ...? Not that ... but ...

35. Peter: But it's like really strong dead bacteria

36. Tony: Yeah, like some sort of poison

37. Peter: It's effective against viral infections

/.../

38. Felicia: Yeah, yeah. It's good at killing viruses 
At the start of the excerpt, Felicia focuses on the idea that "antibiotics are killing" (21) "diseases" (23), which implies that she starts the discussion from an everyday discursive perspective. Between her utterances, Peter adds that antibiotics will kill bacteria (22), thereby asserting the correct relationship between antibiotics and bacteria. Tony seems to capture Peter's claim and concludes that the statement in the task must be wrong (24). Therefore, the correct answer was already mentioned at the start of the conversation. However, this does not lead to the group establishing a relationship between these words, which indicates that they never stand fast in the conversation. In a following utterance, Tony underlines his previous statement by using his everyday experience when he claims, "I have had some sort of viral infection. I got no antibiotics" (25). Instead of building on this claim, Felicia starts to question when humans need antibiotics through asking and responding to her own questions: "What do you get antibiotics against ... it's against viruses, isn't it," (26) and later "What do antibiotics contain?" (32). These two questions may be a way for her to logically try to derive when antibiotics are needed and how they are used. Tony tries to answer the first of Felicia's questions by pointing out that "It's against tonsillitis and such" (27), although this complicates things even more, as tonsillitis may be either a virus or a bacterial infection. Nevertheless, Felicia only focuses on the virus solution and suggests that tonsillitis must be a virus (28). At the end of the conversation, Tony and Peter return to the idea that antibiotics are a kind of poison that kills bacteria, and Peter states, "It's like really strong dead bacteria" (35). However, they still do not explicitly establish this relationship at this point. An obvious indication of this is Peter's next statement "It's effective against viral infections" (37) and Felicia's concluding comment "It's good at killing viruses" (38), which also summarizes and ends the group discussion.

This conversation is somewhat confusing, as the participants shift ideas when it comes to determining if antibiotics are a cure against bacteria or viruses. An example of this is Peter's statements that antibiotics are used against bacterial infections $(22,35)$ and later that they are "effective against virus infections" (37). These statements do not help establish the correct relationship and serve to complicate the group's attempts to reach the correct answer. However, a major reason why this group did not reach the solution is that they did not manage to establish a solid relationship between bacteria, virus, and the function of antibiotics, so this relationship never stands fast in the conversation. It is actually never the subject of an explicit negotiation, which hinders the students from using it as a starting point in explaining the function of antibiotics in relation to a more scientific discourse.

In the fourth example, students in another group try to determine the trustworthiness in statements 1 and 3 (Vaccination is an attempt to use the body's own immune system against diseases and Antibiotic treatment is effective against viral diseases such as smallpox). 
Excerpt 4 from school L2: Karin and Jane

39. Karin: Yeah, well it is ... well it is, because once we've taken the syringe (...inaudible), you have got some of the disease

40. Jane: (simultaneously) Well it is, when you take the syringe, you get some of it so that you will strengthen the immune system

/.../

41. Jane: Uhh. Don't you usually take ...? (referring to statement 3 )

42. Karin: So, my ma ...

43. Jane: Don't you usually take antibiotics when there is, like, no cure?

44. Karin: My ma had a viral infection

45. Jane: Yeah. Did she take antibiotics?

46. Karin: Then she got antibiotics

47. Jane: When you, like, catch a cold. It's a virus, isn't it? Didn't someone in our class once say that she ... when you have a cold too long you get antibiotics ... or ...?

48. Karin: I don't know

49. Jane: So that she (...inaudible)

50. Karin: We take 'Yes'

51. Jane: We take 'Yes'. Yes, that you strengthen

Karin starts the discussion about the first statement by claiming that "once we've taken the syringe (...inaudible), you have got some of the disease" (39). Jane simultaneously expresses the same idea, saying that it also means to "strengthen the immune system" (40). Both statements are relevant in relation to the first statement in the task, but this does not lead to any further elaboration. On the other hand, the students discuss the statement sufficiently to correctly respond to the statement. The students continue the discussion by referring to the third statement. Jane asks, "Don't you usually take antibiotics when there is, like, no cure?" (43). In doing so, she likely wants to emphasize that there are restrictions on when to use antibiotics. Karin then tries to respond to the statement by using her own everyday experience, claiming that her "ma had a viral infection" (44) and "then she got antibiotics" (46). By these statements, Karin seems to lean toward the conclusion that the primary use of antibiotics is for viral infections. This implication is further strengthened when she proposes that the third statement is correct by saying, "We take "Yes" (50). Jane agrees with this final conclusion of the group (51) and seems to relate severe viral infection to antibiotic treatment in the earlier utterance: "When you, like, catch a cold. It's a virus, isn't it? Didn't someone in our class once say that she ... when you have a cold too long you get antibiotics" (47). The conversation in this group is mainly conducted within an everyday discourse related to the students' own experiences of diseases, rather than attempts to provide explanations concerning the function of antibiotics, based on the scientific words virus and especially bacteria. The students do not mention bacteria at all. In fact, there is no evidence that the students notice, distinguish, or are aware of the semantic relationship (Lemke, 1990) between these specific scientific terms. This can be related to an everyday, Swedish discourse and common, everyday perspectives that 
do not make a clear distinction between viruses and bacteria. This may also be illustrated by an utterance in group L4 (see Table 2): "Then you usually take antibiotics, because then you have many viruses and all that."

\section{Discussion and Conclusions}

In this study, we aimed to explore secondary students' discursive language use during group interactions and problem-solving in science. This implies a focus on how students define and explain the educational content within everyday or scientific discourses and how their negotiations may influence the outcome of the discussions. In these contexts, several researchers (e.g. Wallace, 2004; Yore \& Treagust, 2006) view science instruction as a hybrid language activity (Bakhtin, 1981), in which scientific expressions are mixed with everyday language use. However, Kambrelis and Wehunt (2012) show that the usage of language in science education usually takes place at an implicit level and that teachers and students seem to adopt a hybrid language without clarifying the contexts in which words and expressions belong. Furthermore, Serder and Jakobsson (2016) assert that the usage of an unconsidered hybrid language in science classrooms may result in increased complexity and risk for misunderstandings. They also note that one way to prevent such a development is to create opportunities for increased awareness about discursive language use in science instruction.

One way of approaching the question of discursive language use in science education is to analyze students' language use in situations of independent problem-solving in small-group interactions. A crucial assumption behind this alignment has been to explore students' natural use of words, expressions, and scientific terms, as well as their colloquial language use (e.g. Jakobsson et al., 2009).

The results in this study indicate that students' negotiations about words and terms are crucial in the process of identifying, specifying, elaborating, and explaining how scientific phenomena are connected. In this study, several students use scientific terms, as well as more general or everyday words and expressions, to elaborate their reasoning in productive ways. For example, by using general and everyday expressions (such as protect against and build up), in combination with scientific terms (such as antibodies), students successfully tie processes and scientific terms together. They can then elaborate their definitions of terms such as vaccination, bacteria, virus, and antibiotics. This process can be related to the importance of being able to logically link terms and words together by using appropriate language resources, such as conjunctions, when explaining scientific phenomena (Halliday \& Martin, 1993; Seah et al., 2011).

The analyses also display similarities and differences between the various excerpts. For example, the discussions in the first two groups (Excerpts 1 and 2) seem to move between everyday wording and a school science discourse in a productive way. In the first excerpt, the students establish a solid relationship between vaccination-build up antibodies-protect against the disease in the future, which then becomes a crucial prerequisite for solving the task. In the second excerpt, the students create a similar relationship between antibiotic treatment-combating bacteria-not virus, thereby also succeeding in delivering the right answer for this statement. Furthermore, the explanations in the second excerpt greatly relate to a micro- or cellular level, which is typical for a scientific approach, and facilitate students to build bridges between everyday and 
scientific expressions. Therefore, it seems that once students establish these relationships, they are standing fast (Wittgenstein, 1969). Therefore, an important conclusion is that this ability to create relationships between various words, expressions, and terms constitutes an important prerequisite in this kind of educational situation. This also includes students' ability to move between different ways of expressing themselves in everyday or scientific wordings. In this way, the first two excerpts constitute examples of how group members establish relationships between words, expressions, and scientific terms, creating conditions necessary for discussing and evaluating the statements.

However, there is not a similar process and outcome in the two latter excerpts. These groups seem to have difficulty establishing corresponding relationships, such as those between bacteria, virus, and the function of antibiotics. Therefore, these important relationships never stand fast (Wittgenstein, 1969). This happens despite the fact that some students actually mention the correct answer during the discussion. This means that the relationship between significant terms and words is never the subject of a negotiation, preventing the students from using them as a starting point in solving the task. Instead, their own everyday experiences of diseases are crucial in the discussions, but in these specific situations, they seldom lead to the students successfully building bridges between their experiences and the school science discourse.

The four excerpts exemplify the group discussions in the analyzed empirical material. The excerpts further illustrate and deepen the understanding of the various discursive language usages within all 10 groups. The analysis shows that three (out of five) group conversations from high-performing school environments are more elaborate and content-specific (Tables 1 and 2, right column). The other conversations (Tables 1 and 2, left and middle columns) mainly consist of everyday vague expressions, which may be linked to the difficulties in defining specific terms and semantically relating them within a scientific knowledge structure and discourse.

The results indicate that the students in the two first excerpts productively use scientific terms to provide more elaborate, specific explanations of the process of vaccination and immunization, while the explanations in the other two excerpts are less elaborate and specific. For example, the words antibodies and white blood cells are not included in the task (Mary Montagu Question 1) and do not occur at all in the group conversations in the last excerpts. Furthermore, when students express themselves within everyday discourse and simultaneously use words and expressions within a scientific discourse, they are able to elaborate their explanations in more specific ways. However, this occurs to a more limited extent in the last two excerpts, which seem to constitute an obstacle when it comes to arriving at the correct solution.

In conclusion, arriving at successful answers involves an ability to move the conversation toward or within a scientific knowledge structure and discourse. The results in this study reveal the intertwined and complex interplay between knowledge-building and language usage and also illustrate distinctive aspects of students' productive discursive mobility. Furthermore, we argue that our results are important because they indicate crucial differences with respect to discursive language usage within various school environments. In this sense, an essential implication is that science education has to focus on school science as a specific language activity. This requires teachers and students to be aware of disciplinary literacy and language, in relation to an everyday language use, so that all students have the opportunity to learn how to master the distinctive features of scientific discourse. 
Acknowledgments The authors are grateful to the teachers and the students who participated in this study.

Funding Information This study was funded by the Marcus and Amalia Wallenberg Foundation (MAW 2012.0094) and the Swedish Research Council (grant number 721-2014-2015).

Compliance with Ethical Standards The project addressed ethical considerations and permissions required to videotape students in class and took into account the prevailing principles of research ethics (Swedish Research Council, 2011) in collecting and processing the material.

Conflict of Interest The authors declare that they have no conflict of interest.

\title{
Appendix
}

PISA task Mary Montagu Question 1 (English version) (2006)

\author{
MARY MONTAGU \\ THE HISTORY OF VACCINATION
}

Mary Montagu was a beautiful woman. She survived an attack of smallpox in 1715, but she was left covered with scars. While living in Turkey in 1717 , she observed a method of inoculation that was commonly used there. A weak type of smallpox was scratched into the skin of a healthy young person, who then became sick for a short time. This brief illness left no scars and never killed people as normal smallpox did. Mary was so convinced of the safety of these inoculations that she allowed her son and daughter to be inoculated. In 1796 Edward Jenner used inoculations of a related disease, cowpox, to evoke antibodies against the far more deadly disease smallpox. Jenner has been called the "father of vaccination". Mary Montagu should be called the "mother of vaccination".

Question 1: MARY MONTAGU

S477Q01-019

Are these statements concerning the treatment of illnesses correct? Circle "Correct" or "Incorrect" in each case.

\begin{tabular}{|l|c|}
\hline Statements & Correct or Incorrect? \\
\hline $\begin{array}{l}\text { Vaccination is an attempt to use the body's own immune } \\
\text { system against disease. }\end{array}$ & Correct / Incorrect \\
\hline $\begin{array}{l}\text { Antibiotic treatment is an attempt to use the body's own } \\
\text { immune system against disease. }\end{array}$ & Correct / Incorrect \\
\hline $\begin{array}{l}\text { Antibiotic treatment is more effective against viral } \\
\text { diseases than it is against bacterial diseases. }\end{array}$ & Correct / Incorrect \\
\hline
\end{tabular}

Open Access This article is distributed under the terms of the Creative Commons Attribution 4.0 International License (http://creativecommons.org/licenses/by/4.0/), which permits unrestricted use, distribution, and reproduction in any medium, provided you give appropriate credit to the original author(s) and the source, provide a link to the Creative Commons license, and indicate if changes were made.

\section{References}

Bakhtin, M. M. (1981). Discourse in the novel. In M. Holquist (Ed.), The dialogic imagination by M. M. Bakhtin (pp. 259-422). Austin, TX: University of Texas Press.

Bhabha, H. K. (1994). The location of culture. London, England: Routledge.

Brown, B. A., \& Spang, E. (2008). Double talk: Synthesizing everyday and science language in the classroom. Science Education, 92(4), 708-732. 
Chin, C.-C., Yang, W. C., \& Tuan, H.-L. (2016). Argumentation in a socioscientific context and its influence on fundamental and derived science literacies. International Journal of Science and Mathematics Education, 14, 603-617.

Clerk, D., \& Rutherford, M. (2000). Language as a confounding variable in the diagnosis of misconceptions. International Journal of Science Education, 22(7), 703-717.

Fang, Z. (2005). Scientific literacy: A systemic functional linguistics perspective. Science Education, 89(2), $335-344$.

Fang, Z. (2006). The language demands of science reading in middle school. International Journal of Science Education, 28(5), 491-520.

Fang, Z., \& Wei, Y. (2010). Improving middle school students' science literacy through reading infusion. Journal of Educational Research, 103(4), 262-273.

Gee, J. P. (1996). Social linguistics and literacies: Ideology in discourses. London, England: Taylor \& Francis.

Gee, J. P. (1999). An introduction to discourse analysis: Theory and method (2nd ed.). New York, NY: Routledge.

Gibbons, P. (2003). Mediating language learning: Teacher interactions with ESL students in a content-based classroom. TESOL Quarterly, 37(2), 247-273.

González-Howard, M., McNeill, K. L., Marco-Bujosa, L., \& Proctor, C. P. (2017). 'Does it answer the question or is it French fries?': An exploration of language supports for scientific argumentation. International Journal of Science Education, 39, 528-547.

Halliday, M. A. K., \& Martin, J. R. (1993). Writing science. Literacy and discursive power. Pittsburgh, PA: University of Pittsburgh Press.

Halliday, M. A. K., \& Matthiessen, C. (2004). An introduction to functional grammar. London, England: Hodder Arnold.

Hand, B., Norton-Meier, L. A., Gunel, M., \& Akkus, R. (2016). Aligning teaching to learning: A 3-year study examining the embedding of language and argumentation into elementary science classrooms. International Journal of Science and Mathematics Education, 14, 847-863.

Hanrahan, M. U. (2006). Highlighting hybridity: A critical discourse analysis of teacher talk in science classrooms. Science Education, 90(1), 8-43.

Jakobsson, A., Mäkitalo, Å. \& Säljö, R. (2009). Conceptions of knowledge in research on students' understanding of the greenhouse effect: Methodological positions and their consequences for representations of knowing. Science Education, 93(6), 978-995.

Kambrelis, G., \& Wehunt, M. (2012). Hybrid discourse practice and science learning. Cultural Studies of Science Education, 7(3), 505-534.

Karlsson, A., Nygård Larsson, P., \& Jakobsson, A. (2018). Multilingual students' use of translanguaging in science classrooms. International Journal of Science Education.https://doi.org/10.1080 /09500693.2018.1477261.

Karlsson, A., Nygård Larsson, P., \& Jakobsson, A. (2019). The continuity of learning in a translanguaging science classroom. Cultural Studies of Science Education.https://doi.org/10.1007/s11422-019-09933-y.

Kelly, G. (2012). Expanding discourse repertoires with hybridity. Cultural Studies of Science Education, 7(3), 535-539.

Knain, E. (2015). Scientific literacy for participation: A systemic functional approach to analysis of school science discourses. Rotterdam, Netherlands: Springer Nature. Sense Publishers.

Lemke, J. L. (1990). Talking science: Language, learning, and values. New York, NY: Ablex Publishing Corporation.

Lindberg, I., \& Johansson Kokkinakis, S. (Eds.). (2007). OrdiL. En korpusbaserad kartläggning av ordförrådet i läromedel för grundskolans senare år [A corpus-based survey of vocabulary in teaching materials for the compulsory school's later years]. Göteborg, Sweden: Institutet för svenska som andraspråk.

Msimanga, A., \& Lelliott, A. (2014). Talking science in multilingual contexts in South Africa: Possibilities and challenges for engagement in learner's home languages in high school classrooms. International Journal of Science Education, 36(7), 1159-1183.

Norris, S. P., \& Phillips, L. M. (2003). How literacy in its fundamental sense is central to scientific literacy. Science Education, 87, 224-240.

Nygård Larsson, P. (2011). Biologiämnets texter. Text, språk och lärande $i$ en språkligt heterogen gymnasieklass [The texts of Biology. Text, language and learning in a heterogenic class in upper secondary school] (Doctoral dissertation). Malmö University, Sweden.

Nygård Larsson, P. (2018). "We're talking about mobility": Discourse strategies for promoting disciplinary knowledge and language in educational contexts. Linguistics and Education, 48, 61-75. 
Nygård Larsson, P. \& Jakobsson, A. (2017). Semantiska vågor - elevers diskursiva rörlighet i gruppsamtal [Semantic waves - discursive mobility in students' small group discussions]. NorDiNa - Nordic Studies in Science Education, 13(1), 17-35.

OECD/PISA. Frisläppta uppgifter naturvetenskap (2006). Skolverket/Mittuniversitet.

Olander, C. (2010). Towards an interlanguage of biological evolution: Exploring students' talk and writing as an arena for sense-making (Doctoral dissertation). Gothenburg University, Sweden.

Rivard, L. P. (2004). Are language-based activities in science effective for all students, including low achievers? Science Education, 88(3), 420-442.

Schleppegrell, M. J. (2013). The role of metalanguage in supporting academic language development. Language Learning. A Journal of Research in Language Studies, 63(1), 153-170.

Seah, L. H. (2016). Elementary teachers' perception of language issues in science classrooms. International Journal of Science and Mathematics Education, 14, 1059-1078.

Seah, L. H., Clarke, D. J., \& Hart, C. E. (2011). Understanding students' language use about expansion through analyzing their lexicogrammatical resources. Science Education, 95(5), 852-876.

Seah, L. H., Clarke, D. J., \& Hart, C. E. (2014). Understanding the language demands on science students from an integrated science and language perspective. International Journal of Science Education, 36(6), 952-973.

Seah, L. H., \& Yore, L. D. (2017). The roles of teachers' science talk in revealing language demands within diverse elementary school classrooms: A study of teaching heat and temperature in Singapore. International Journal of Science Education, 39(2), 135-157.

Serder, M. \& Jakobsson, A. (2016). Language games: The meaning potentials of scientific literacy surveys. Science Education, 100(2), 321-343.

Swedish Research Council. (2011). Good research practice. Stockholm, Sweden: Swedish Research Council.

Tan, E., Calabrese Barton, A., Turner, E., \& Gutiérrez, M. V. (2012). Empowering science and mathematics education in urban schools. Chicago, IL: University of Chicago Press Books.

Wallace, C. S. (2004). Framing new research in science literacy and language use: Authenticity, multiple discourses, and the 'third space'. Science Education, 88(6), 901-914.

Wickman, P. O. (2004). The practical epistemologies of the classroom: A study of laboratory work. Science Education, 88(3), 325-344.

Wickman, P. O., \& Östman, L. (2002). Learning as discourse change: A sociocultural mechanism. Science Education, 86(5), 601-623.

Wittgenstein, L. (1953/1997). Philosophical investigations. Oxford, England: Blackwell.

Wittgenstein, L. (1969). Uber gewissheit [On certainty]. New York, NY: Harper \& Row.

Yore, L. D., \& Treagust, D. F. (2006). Current realities and future possibilities: Language and science empowering research and informing instruction. International Journal of Science Education, 28(2-3), 291-314. 